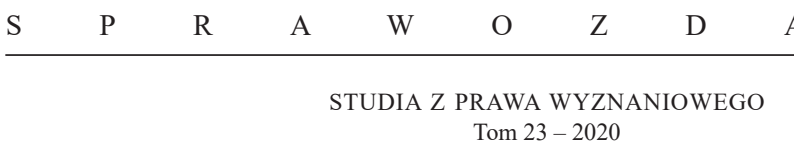

DOI: https://doi.org/10.31743/spw.12242

MICHAŁ CZELNY*

\title{
XVII OGÓLNOPOLSKIE SYMPOZJUM PRAWA WYZNANIOWEGO PT. ORZECZNICTWO W SPRAWACH WYZNANIOWYCH, Kombornia, 22-24 września $2020 \mathrm{r}$.
}

W dniach 22-24 września 2020 r. w Komborni odbyło się XVII Ogólnopolskie Sympozjum Prawa Wyznaniowego pt. Orzecznictwo w sprawach wyznaniowych. Jego organizatorem był Instytut Nauk Prawnych Uniwersytetu Rzeszowskiego, Instytut Teologiczno-Pastoralny w Rzeszowie, oraz Polskie Towarzystwo Prawa Wyznaniowego. Z powodu panującej epidemii COVID-19 i wymogów reżimu sanitarnego istniała możliwość wzięcia w nim udziału osobiście lub zdalnie.

Uroczystego otwarcia konferencji dokonał Prezes Polskiego Towarzystwa Prawa Wyznaniowego prof. ASzWoj, dr hab. Marek Bielecki (Akademia Sztuki Wojennej w Warszawie).

Sesji pierwszej przewodniczył prof. Marek Bielecki. W czasie jej trwania referaty wygłosili: prof. UO, dr hab. Paweł Sobczyk pt. Ars iuris w sprawach wyznaniowych; prof. dr hab. Tadeusz J. Zieliński (ChAT) pt. Judykatura $w$ sprawach wyznaniowych $w$ Republice Irlandii; ks. prof. UO, dr hab. Dariusz Walencik pt. Orzecznictwo TK, SN i NSA dotyczace komisji regulacyjnych; ks. prof. UZ, dr hab. Tadeusz Stanisławski pt. Indywidualne interpretacje podatkowe $w$ wyznaniowych sprawach gospodarczych; ks. prof. dr hab. Artur Mezglewski (ASzWoj) pt. Odmowa udostępnienia wizerunku twarzy ze względu na zakaz ujawniania przekonań religijnych lub filozoficznych $w$ orzecznictwie administracyjnym i sadowoadministracyjnym. Opinia biegłego, a także dr Justyna Krzywkowska (UWM) pt. Odmowa zgody na rozwód podyktowana względami religijnymi.

* Ks. mgr lic., Katedra Prawa Wyznaniowego, Wydział Prawa, Prawa Kanonicznego i Administracji, Katolicki Uniwersytet Lubelski Jana Pawła II, Al. Racławickie 14, 20-950 Lublin, e-mail: mczelny@kul.pl. ORCID 0000-0003-1420-4090. 
Po ich wygłoszeniu nastąpiła krótka dyskusja, a po 15-minutowej przerwie, w ramach programu Sympozjum, dokonano uroczystego wręczenia Księgi Jubileuszowej dedykowanej ks. prof. dr. hab. Arturowi Mezglewskiemu. Następnie wszyscy uczestnicy udali się na uroczystą kolację.

Drugi dzień obrad rozpoczął się od dwóch sesji równoległych. Pierwszej przewodniczył ks. prof. KUL, dr hab. Piotr Stanisz. W czasie jej trwania swoje referaty wygłosili: dr hab. Rafał Łatka (IPN) pt. Procesy polityczne duchownych w okresie Polski Ludowej; prof. UO, dr hab. Andrzej Szymański pt. Sprawa ks. Alfonsa Millera. Oskarżenie - śledztwo wyrok - uwolnienie; mgr Tomasz Resler (UWr) pt. Przedwojenne ustawy wyznaniowe - wybrane problemy we wspótczesnym orzecznictwie sadowym oraz prof. ASzWoj, dr hab. Marek Bielecki pt. Wptyw orzecznictwa na sytuację prawna Świadków Jehowy w Polsce w kontekście bezpieczeństwa państwa. Drugiej, równoległej sesji, przewodniczyła dr Justyna Krzywkowska. W czasie jej trwania referaty wygłosili: prof. UO, dr hab. Jerzy Nikołajew pt. Dyskryminacja ze względu na bezwyznaniowość w pracy. Rozważania na kanwie orzeczeń sadowych zapadtych w sprawie Grażyny Juszczyk; dr Krystyna Ziółkowska (UWM) pt. Orzecznictwo w sprawach o dyskryminacje $w$ miejscu pracy ze względu na wyznanie oraz ks. dr Marek Paszkowski (UWM) pt. Zatrudnianie przez Kościół Katolicki a zasada niedyskryminacji ze względu na religię lub przekonania. Po każdej sesji odbyła się przewidziana w programie dyskusja.

Po przerwie kawowej rozpoczęły się dwie kolejne, równoległe sesje. Pierwszej przewodniczył ks. prof. UZ, dr hab. Tadeusz Stanisławski. W czasie jej trwania swoje referaty wygłosili: dr Marcin Olszówka (Uczelnia Łazarskiego) pt. Symbole religijne w budynkach publicznych - synteza polskiej judykatury w III RP; dr Michał Poniatowski (UKSW) pt. Wartości chrześcijańskie w orzecznictwie SN oraz sadów powszechnych; dr Michał Skwarzyński (KUL) pt. Standard ochrony przed bluźnierstwem w orzecznictwie ETPCz a rola sadu krajowego oraz mgr Katarzyna Pluta (UO) pt. Udzielenie ateiście sakramentu namaszczenia chorych a naruszenie jego dóbr osobistych. Wybrane orzecznictwo SN. Drugiej, równoległej sesji przewodniczyła prof. ASzWoj, dr hab. Marzena Toumi. W czasie jej trwania swoje referaty wygłosili: ks. prof. UWM, dr hab. Mieczysław Różański pt. Uzyskanie osobowości prawnej w orzecznictwie sądowym; prof. KUL, dr hab. Anna Tunia pt. Wykorzystanie dróg i placów publicz- 
nych przez wyznaniowe jednostki organizacyjne na potrzeby działalności własnej. Uwagi na tle orzecznictwa sadów powszechnych oraz dr Marta Osuchowska (UKSW) pt. Edukacja religijna w szkołach publicznych a zasada neutralności państwa. Uwagi na tle wyroku Sąu Najwyższego Argentyny z 2017. Po każdej sesji odbyła się przewidziana w programie krótka dyskusja.

Ostatnia sesja Sympozjum odbyła się w trybie online. Jej moderatorem był prof. ASzWoj, dr hab. Marek Bielecki. Stacjonarni uczestnicy Sympozjum przebywający w Komborni mogli wysłuchać następujących referatów: prof. UW, dra hab. Wojciecha Brzozowskiego pt. Zakaz zastaniania twarzy w miejscach publicznych - między Europejskim Trybunałem Praw Człowieka a Komitetem Praw Człowieka ONZ; dr Anety M. Abramowicz (KUL) pt. Kwestia cywilnej skuteczności religijnych regut spadkobrania $w$ świetle orzeczenia ETPCz z dnia 19 grudnia 2018 r. w sprawie Molla Sali v. Grecja; dra Michała Zawiślaka (KUL) pt. Świeckość państwa francuskiego w świetle orzecznictwa; dra Marka Strzały (UJ), pt. Wybrane hiszpańskie orzecznictwo dotyczace stosowania prawa kanonicznego w obrocie cywilnoprawnym; dra Mariusza Grabowskiego (UKSW) pt. Problem ochrony uczuć religijnych przed ich naruszaniem $w$ sferze radiofonii i telewizji w świetle orzecznictwa i stanowisk Trybunatu Konstytucyjnego; dra Macieja Kubali, Lekarska klauzula sumienia w orzecznictwie Trybunału Konstytucyjnego RP; dra Michała Ożoga (UJ) pt. Orzecznictwo $w$ sprawach ustanowienia patrona wspólnoty samorzadowej $w$ perspektywie rozwoju ochrony wolności sumienia i religii oraz dra Konrada Zamirskiego (ChAT) pt. Status Międzykościelnej Komisji Regulacyjnej w świetle orzecznictwa sadów administracyjnych i Trybunału Konstytucyjnego w Polsce.

Następnie wszyscy uczestnicy udali się na uroczysty obiad i zwiedzanie okolicy. Po powrocie w programie konferencji miała miejsce dyskusja końcowa i zamknięcie Sympozjum. Dokonał go Prezes Polskiego Towarzystwa Prawa Wyznaniowego prof. ASzWoj, dr hab. Marek Bielecki, który podziękował organizatorom za przygotowanie i przebieg Sympozjum, zaś wszystkim uczestnikom za przybycie, wygłoszenie referatów i aktywny udział w dyskusjach. W swoim wystąpieniu podkreślił, że podjęta tematyka Sympozjum okazała się niezwykle potrzebna. Jej aktualność można było zauważyć w wielości wygłoszonych referatów i to z różnych 
obszarów na gruncie prawa wyznaniowego. Planowana publikacja pokonferencyjna pozwoli jeszcze raz spojrzeć na niezmiernie ciekawą tematykę przedłożonych wystąpień. 